\title{
Pelaksanaan Penimbangan Jual Beli Biji Coklat Dalam Tinjauan Ekonomi Islam : Studi Desa Bulili Kecamatan Nokilalaki Kabupaten Sigi
}

Nursyamsu Nursyamsu1*, Moh. Idham 2, Ferdiawan Ferdiawan ${ }^{3}$

${ }^{1}$ Ekonomi Syariah, Fakultas Ekonomi dan Bisnis Islam, IAIN Palu

2 Ekonomi Syariah, Fakultas Ekonomi dan Bisnis Islam, IAIN Palu

${ }^{3}$ Ekonomi Syariah, Fakultas Ekonomi dan Bisnis Islam, IAIN Palu

ABSTRAK

Penelitian ini bertujuan mengkaji penimbangan Jual Beli Biji Coklat Dalam Tinjauan Ekonomi Islam (Studi Kasus Desa Bulili Kecamatan Nokilalaki Kabupaten Sigi). Dengan mengangkat masalah bagaimana pelaksanaan penimbangan jual beli biji coklat yang ada di desa Bulili Kecamatan Nokilalaki Kabupaten Sigi serta bagaimana tinjauan ekonomi Islam yang ada di desa Bulili Kecamatan Nokilalaki Kabupaten Sigi. Penelitian ini menggunakan metode kualitatif deskriptif dengan lokasi penelitian di desa Bulili, Kecamatan Nokilalaki, Kabupaten Sigi. Sumber data diperoleh melalui observasi, wawancara,dan dokumentasi. Sedangkan teknik analisis data yang digunakan adalah reduksi data, penyajian data dan verifikasi data. Hasil penelitian menunjukkan bahwa pelaksanaan penimbangan jual beli biji coklat di Desa Bulili menggunakan sistem timbangan yang manual dan juga atas dasar suka sama suka antara penjual dan pembeli Dalam tinjauan hukum ekonomi Islam, beli biji coklat yang di terapkan di Desa Bulili merupakan bentuk jual beli yang dibolehkan dalam hukum Islam.
INFORMASI

ARTIKEL

Katakunci:

Jual beli, penimbangan, ekonomi Islam, biji coklat 


\section{Pendahuluan}

Islam sebagai agama yang universal telah melakukan penekanan bahwa pentingnya memberikan faedah dalam proses perniagaan dan juga memperhatikan nilai-nilai yang berhubungan dengan moral sebagai pelaku ekonomi. Dan diantara yang diwajibkan oleh Allah dalam jual-beli adalah memenuhi takaran dan timbangan secara adil. Di dalam AlQur'an juga Allah dengan jelas dan tegas mengancam orang yang curang dalam timbangan, Surat Al-Muthafifin ayat 1-3 yang berbunyi:

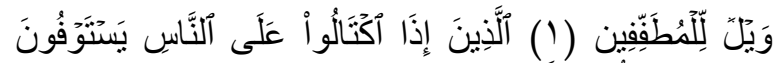

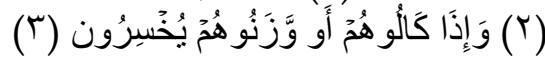

Terjemahanya:

Kecelakaan besarlah bagi orangorang yang curang, (yaitu) orangorang yang apabila menerima takaran dari orang lain mereka minta dipenuhi, dan apabila mereka menakar atau menimbang untuk orang lain, mereka mengurangi. ${ }^{1}$

Dari penjelasan ayat di atas sudah sangat jelas bahwa di dalam Islam tidak di benarkan adanya kecurangan di dalam melakukan penimbangan, tidak boleh mengurangi dan melakukan kecurangan. Hal semacam itu hanya akan merugikan bagi para konsumen dan orang yang melakukan kecurangan akan mendapatkan kemurkaan dari Allah SWT.

$$
\text { Adapun yang menjadi }
$$

permasalahan dalam praktek penimbangan dalam jual beli biji coklat

\footnotetext{
${ }^{1}$ Departemen Agama RI, Al-Qur'an dan Terjemahnya, (Marwah: Bandung, 2009), 587.
}

di Desa Bulili adalah cara pembeli dalam pelaksanaan penimbangan dan pemotongan. Berdasarkan hasil observasi yang di lakukan oleh penulis, banyak menemukan praktek perilaku pemotongan timbangan yang di lakukan oleh para pengepul coklat biji. Sehingga dari kasus tersebut terdapat dugaan kecurangan dalam timbangan, maka oleh sebab itu berdasarkan latar belakang masalah di atas penulis tertarik untuk meneliti dalam bentuk karyakarya ilmiah selanjutnya.

Sampai sejauh ini penulis telah membahas proses penghapusan dasar penipuan dalam ekonomi sebagai salah satu kepentingan utama dalam system keadilan. $^{2}$ Pelanggaran nilai etika mungkin atau tidak menimbulkan kerugian seketika atau kerugian yang dapat dilihat oleh pihak-pihak yang melakukanya. Tetapi pelanggaran nilai etika biasanya akan melibatkan sedikit banyak kerugian bagi orang lain. Islam menganjurkan agar nilai etika dijunjung tinggi dalam kehidupan terutama dalam dunia perdagangan. Dengan demikian aspek ekonomi Islam ini diselesaikan secara tuntas, guna menghindari terjadinya pertikaian dan kejanggalan dalam kehidupan sosial masyarakat sehingga dengan tuntutan syariat Islam tersebut, oleh karena itu aspek ekonomi secara Islami sangat penting bagi kelangsungan kehidupan sehari-hari, karena ekonomi Islam tidak hanya mementingkan kepentingan dunia saja, melainkan memikirkan kepentingan akhirat. Kejujuran dan kebenaran merupakan nilai yang terpenting.

\footnotetext{
${ }^{3}$ Muhammad Nejjatulloh Siddiqi, Kegiatan Ekonomi Dalam Islam, 57.
}

e-ISSN: $2686-6633$ 
Sehubungan dengan hal tersebut, penipuan, sikap eksploitasi orang lain yang tidak bersalah dan orang yang jahil atau membuat pernyataan palsumerupakan perbuatan yang dilarang. ${ }^{3} \quad$ Kezaliman bermaksud meletakkan suatu perkara (benda) ditempat yang bukan sebenarnya. Dan sebaliknya, keadilan bermaksud meletakkan suatu perkara (benda) di tempat yang sebenarnya. Definisi yang penting ini selanjutnya membentuk sifat yang luas dan positif tentang ide keadilan dalam Islam.4

Salah satu kegiatan ekonomi yang diatur dalam Islam adalah perniagaan atau jual beli. Perdagangan atau jual beli menurut bahasa berarti al $B a^{\prime} I$, al-Tijarah dan al-Mubadalah.5 Dalam jual beli hendaknya disertai rasa jujur sehingga ada nilai manfaatnya. Apabila penjual dan pembeli saling tipu menipu atau merahasiakan tentang apa yang seharusnya dikatakan maka tidak ada nilai manfaat. ${ }^{6}$ Islam sangat menghargai sikap kejujuran dan melarang sikap khianat. Oleh sebab itu, seorang muslim yang menjadi pelaku bisnis hendaknya taat pada janji dan amanat. Dilarang berkhianat pada siapapun, apalagi kepada mitra bisnis termasuk pelanggan atau konsumen.

Islam juga melarang manusia melakukan kebohongan, termasuk kebohongan dalam berbisnis. Peringatan ini sangat aktual, jika kita melihat berbagai kebohongan dalam praktek

${ }^{3}$ Ibid, 57.

${ }^{4}$ Ibid, 58.

${ }^{5}$ Hedi Suhendi, Fiqih Muamalah, (Jakarta: PT Raja Grafindo, 2002), 67.

${ }^{7}$ Ahmad Mudjab Mahallf, Ahmad Rodh Hasbulloh, Hadis-hadis Muttafaq 'Alaih, (Cet-1; Jakarta: Kencana, 2004), 97. bisnis dalam keseharian. Selanjutnya Allah Swt mengingatkan kecenderungan terjadinya kecurangan dalam kehidupan bermasyarakat, termasuk masyarakat dunia usaha. Tuhan mengingatkan sikap ini dengan kebiasaan buruk manusia untuk meminta haknya tetapi terbiasa mengurangi hak orang lain.

Dalam hal ini konsumen atau pembeli yang merasa tertipu, bukan yang hal baru lagi. Sering terungkap barang yang dibeli tidak sesuai dengan barang yang ditawarkan atau diiklankan. Atau ukuran barang tidak sesuai dengan yang disebutkan atau yang disepakati. Lebih sering lagi timbangan yang tidak sesuai dengan berat barang yang dibayar. Apabila di cermat dengan baik, konsumen dapat mencoba memeriksa kembali berat kemasan barang, misalnya berat gula atau beras yang kita beli. Kemungkinan berat yang berlabel $1 \mathrm{~kg}$ hanya berisi 0,9 $\mathrm{kg}$, atau yang berlabel $20 \mathrm{~kg}$ hanya berbobot 19,5 juga sering menyaksikan atau mungkin mengalami rasa tidak puas karena pelayanan pada konsumen tidak seperti yang di harapkan.

\section{Tinjauan Pustaka}

2.1 Pengertian Jual Beli

Jual beli dalam istilah fiqih disebut dengan al-bai' yang berarti menjual, mengganti dan menakar sesuatu dengan sesuatu yang lain. ${ }^{7}$ Kata alba'u dalam bahasa Arab terkadang digunakan untuk pengertian lawanya, yaitu kata assira'u (beli). Dengan demikian kata $A l-B a i^{\prime} u$ berarti kata jual

${ }^{7}$ Nasrun Haroen, Fiqih Muamalah, (Jakarta: Gaya Media Pratama, 2007), 111.

e-ISSN: $2686-6633$ 
dan sekaligus juga berarti kata beli. ${ }^{8}$ Jual beli secara bahasa artinya memindahkan hak milik terhadap benda dengan akad saling mengganti. ${ }^{9}$ Jual beli adalah tukar menukar satu harta dengan harta yang lain melalui jalan suka sama suka. Pada masyarakat primitif, jual beli biasanya dilakukan dengan tukar menukar barang (harta), tidak dengan uang pada masyarkat pada umumnya. Seperti menukarkan rotan (hasil hutan) dengan pakaian, garam dan sebagainya yang menjadi keperluan pokok mereka sehari-hari. ${ }^{10}$

Dari beberapa definisi di atas dapat dipahami bahwa inti jual beli adalah suatu perjanjian tukar menukar benda atau barang yang mempunyai nilai secara sukarela diantara kedua belah pihak, yang satu menerima bendabenda dan pihak lain menerimanya sesuai dengan perjanjian atau ketentuan yang telah ditetapkan syara' dan disepakati. ${ }^{11}$ Aspek yang terpenting dalam berekonomi dalam kehidupan sosial masyarakat adalah menyangkut masalah jual beli, mengenai jual beli itu sendiri pengertianya adalah tukar menukar satu harta dengan harta yang lainnya melalui jalan suka sama suka. Atau pertukaran harta atas dasar saling rela, yaitu memindahkan hak milik

${ }^{8}$ M Ali Hasan, Berbagai Macam Transaksi Dalam Islam, (Cet-2; Jakarta: PT Raja Grafindo, 2004), 113.

${ }^{9}$ Abdul Aziz Muhammad Azzam, Fiqih Muamalat Sistem Transaksi Dalam Islam, (Jakarta: AMZAH, 2014), 23.

${ }^{10} \mathrm{M}$. Ali Hasan, 115.

${ }^{11}$ Hedi Suhendi, Fiqih Muamalah, (Jakarta: PT Raja Grafindo, 2002), 69. kepada seseorang dengan ganti rugi yang dapat dibenarkan. ${ }^{12}$

\subsection{Rukun dan Syarat Jual Beli}

Rukun dan syarat jual beli adalah merupakan suatu kepastian. Tanpa adanya rukun dan syarat tentulah tidak akan terlaksana menurut hukum, karena rukun dan syarat tidak bisa dikesampingkan dari suatu perbuatan dan juga termasuk bagian dari perbuatan tersebut.

Jual beli adalah merupakan suatu akad, dan dipandang sah apabila telah memenuhi rukun dan syarat jual beli. ${ }^{13}$ Dalam menentukan rukun jual beli, terdapat perbedaan pendapat ulama Hanafiyah dengan jumhur ulama. Rukun jual beli menurut ulama Hanafiyah hanya satu, yaitu ijab (ungkapan pembeli dari pembeli) dan qabul (ungkapan menjual dan penjual). Menurut mereka yang menjadi rukun dalam jual beli itu hanyalah kerelaan (rida/tara'dhi) kedua belah pihak untuk melakukan transaksi jual beli. ${ }^{14}$

Akan tetapi, jumhur ulama menyatakan bahwa rukun jual beli itu ada empat, yaitu:

1. Ada orang yang berakad atau almuta'aqidain (penjual dan pembeli).

2. Ada sighad (lafal ijab dan qabul).

3. Ada barang yang dibeli.

4. Ada nilai tukar pengganti barang. ${ }^{15}$

Menurut ulama Hanafiyah, orang yang berakad, barang yang dibeli, dan

${ }^{12}$ Sayyid Sabiq, Fiqih Sunnah.Alih bahasa Oleh Mohd. Thalib, (Cet-1; Bandung: PT alMa'ruf,1998), 47-48.

${ }^{13}$ M. Ali Hasan, Berbagai Macam Transaksi dalam Islam, 118.

${ }^{14}$ Nasrun Haroen, Fiqih Muamalah, (Jakarta: Gaya Media Pratama, 2007), 115.

${ }^{15}$ Ibid, 115.

e-ISSN: 2686-6633 
nilai tukar barang termasuk kedalam syarat-syarat jual beli, bukan rukun jual beli.

Adapun syarat-syarat jual beli sesuai dengan rukun jual beli yang dikemukakan jumhur ulama di atas adalah sebagai berikut: ${ }^{16}$

1. Syarat orang yang berakad

Para ulama fiqih sepakat menyatakan bahwa orang yang melakukan akad jual beli itu harus memenuhi syarat salah satunya berakal. Oleh sebab itu, jual beli yang dilakukan anak kecil yang belum berakal dan orang gila, hukumnya tidak sah. Adapun anak kecil yang mumayyiz, menurut ulama Hanafiyah, apabila akad yang dilakukan membawa keuntungan bagi dirinya, seperti menerima hibah, wasiat, dan sedekah, maka akadnya sah. yang melakukan akad itu orang yang berbeda. Artinya, seorang tidak dapat bertindak dalam waktu yang bersamaan sebagai penjual sekaligus pembeli.

2. Syarat yang terkait dengan ijab qabul

Menurut mereka ijab dan qabul perlu diungkapkan secara jelas dalam transaksi-transaksi yang bersifat mengikat kedua belah pihak, seperti akad jual beli, akad sewa menyewa, dan akad nikah. Terhadap transaksi yang sifatnya mengikat salah satu pihak, seperti wasiat, hibah, dan waqaf, tidak perlu qabul, karena akad seperti itu cukup dengan ijab saja.

Apabila ijab telah diucapkan dalam akad jual beli, maka kepemilikan barang atau uang telah berpindah tangan dari pemilik semula. Yaitu barang yang dibeli oleh seorang pembeli

${ }^{16}$ Ibid, 115-119. telah menjadi pemilik si pembeli dan sebaliknya.

Untuk itu, para ulama fiqih mengemukakan bahwa syarat ijab dan qabul itu adalah sebagai berikut: ${ }^{17}$

a. Orang yang mengucapkan telah baligh dan berakal, menurut jumhur ulama, atau telah berakal, menurut ulama Hanafiyah sesuai dengan perbedaan mereka dalam syaratsyarat orang yang melakukan akad yang disebutkan di atas.

b. Ijab dan qabul itu dilakukan dalam satu majelis. Artinya, kedua belah pihak yang melakukan jual beli hadir dan membicarakan topik yang sama. Ulama Hanafiyah dan Malikiyah mengatakan bahwa antara ijab dan qabul bisa saja diantarai oleh waktu, yang diperkirakan bahwa pihak pembeli sempat untuk berpikir. Namun, ulama Syafi'iyah dan Hanabilah berpendapat bahwa jarak antara ijab dan qabul tidak terlalu lama, yang dapat menimbulkan dugaan bahwa objek pembicaraan telah berubah.

Di zaman modern perwujudan ijab dan qabul tidak lagi diucapkan, tetapi dilakukan dengan sikap mengambil barang dan membayar uang dari pembeli, serta menerima uang dan menyerahkan barang oleh penjual, tanpa ucapan apapun. ${ }^{18}$ Misalnya, jual beli yang berlangsung dipasar swalayan. Dalam fiqih Islam, jual beli seperti ini disebut dengan ba'ial-mu'athah. Jumhur

\footnotetext{
${ }^{17}$ Nasrun Haroen, Fiqih Muamalah, 116.

${ }^{18}$ Nurdin, N., Novia, N., Rahman, A., \&
} Suhada, R. (2019). Potensi Industri Produk Makanan Halal Di Kota Palu. Jurnal Ilmu Ekonomi dan Bisnis Islam, 1(1), 1-12. 
ulama berpendapat bahwa jual beli seperti kebiasaan suatu masyarakat disuatu negeri. Karena hal itu telah menunjukan unsur ridha dari kedua belah pihak.

c.

3. Syarat barang yang dijual belikan

a. Barang itu ada, atau tidak ada ditempat, tetapi pihak penjual menyatakan kesanggupanya untuk mengadakan barang itu.

b. Dapat bermanfaat dan dapat dimanfaatkan bagi manusia. Oleh sebab itu bangkai, khamer dan darah, tidak sah menjadi objek jual beli, karena dalam pandangan syara' benda-benda seperti itu tidak bermanfaat bagi muslim.

c. Milik seseorang. Barang yang sifatnya belum dimiliki seseorang tidak boleh diperjualbelikan.

d. Boleh diserahkan saat akad berlangsung, atau pada waktu yang disepakati bersama ketika transaksi berlangsung.

4. Syarat-syarat nilai tukar

Terkait dengan masalah nilai tukar ini, para ulama fiqih membedakan at-tsaman deengan as-si'r. Menurut mereka, at-tsaman adalah harga pasar yang berlaku di tengah-tengah masyarakat secara aktual, sedangkan as$s^{\prime} r$ adalah modal yang seharusnya diterima para pedagang sebelum diterima oleh konsumen.

Dengan demikian, dapat diartikan bahwa antara harga untuk sesama pedagang dengan harga untuk pembeli harus dibedakan, dalam praktek seperti ini seperti yang terjadi pada toko grosir yang melayani pembelian eceran dan sekala besar.
5. Syarat-syarat at-tsaman sebagai berikut: 19

a. Harga yang disepakati oleh kedua belah pihak, harus jelas jumlahnya.

b. Boleh diserahkan pada waktu akad, apabila harga barang itu diserahkan kemudian (berhutang), maka waktu pembayaranya harus jelas.

c. Apabila jual beli itu dilakukan dengan saling mempertukarkan barang, maka barang yang dijadikan nilai tukar bukan barang yang diharamklan syara'.

\section{Metode Penelitian}

Metode merupakan suatu prosedur tata cara megetahui sesuatu yang mempunyai langka sistematis. ${ }^{20}$ Dalam penulisan karya ilmiah, penulis menggunakan metode pendekatan kualitatif dan jenis penelitian deskriptif. Metode kualitatif dapat digunakan untuk mengungkap dan memahami sesuatu di balik fenomena yang sedikit pun belum diketahui. ${ }^{21}$ Metode ini dapat juga digunakan untuk menambah wawasan tentang sesuatu yang belum diketahui. $^{22}$ Peneliti dalam penelitian

${ }^{19}$ Ibid, 119.

20 Muhammad, Metodologi Penelitian Ekonomi Islam Pendekatan kualitatif, (Jakarta: Rajawali PT. Raja grafindo Persada, 2008), 12.

21 Nurdin, N. (2019). Knowledge Integration Strategy in Islamic Banks. In A. Helena \& S. Bernardete (Eds.), The Role of Knowledge Transfer in Open Innovation (pp. 118138). IGI Global. https://doi.org/10.4018/978-15225-5849-1.ch006

22 Ansel Struss dan Julet Corbin, DasarDasar Penelitian Kualitatif, (Yogyakarta : Pustaka pelajar, 2007), 5 .

e-ISSN: $2686-6633$ 
kualitatif ini akan mencoba mengerti makna suatu kejadian atau peristiwa dengan mencoba berinteraksi dengan orang-orang dalam situasi/fenomena tersebut.

Penggunakan metode kualitatif dalam penelitian ini dengan beberapa pertimbangan. Pertama, menyesuaikan metode kualitatif lebih mudah apabila berhadapan dengan kenyataan ganda. Kedua, dapat menyajikan secara langsung hakikat hubungan antara peneliti dengan informan ${ }^{23}$. Ketiga, Metode ini lebih peka dan lebih menyesuaikan diri dengan banyak penajaman pengarah bersama dan terhadap pola-pola nilai yang dihadapi. ${ }^{24}$

Lokasi yang menjadi tempat penelitian adalah di Desa Bulili Kecamatan Nokilalaki Kabupaten Sigi. Dipilihnya lokasi penelitian ini karena sangat relevan dengan objek yang di teliti dan juga memberikan nuansa baru bagi penulis dalam menambah pengetahuan, khususnya dalam Pelaksanaan Penimbangan Jual Biji Coklat Dalam Tinjauan Ekonomi Islam.

Data dikumpul dengan menggunakan teknik observasi, wawancara mendalam dan kajian dari

${ }^{23}$ Nurdin, N., Pettalongi, S. S., \& Yusuf, K. (2018). Knowledge Management Model in Syariah Banking. 2018 5th International Conference on Information Technology, Computer, and Electrical Engineering (ICITACEE),

24 Nurdin, N., Stockdale, R., \& Scheepers, H. (2014). The Role of Social Actors in the Sustainability of E-Government Implementation and Use: Experience from Indonesian Regencies. System Sciences (HICSS), 2014 47th Hawaii International Conference on System Science, berbabagi dokumen tertulis ${ }^{25}$. Sedangkan analisa data dilakukan dengan menggunakan teknik reduksi dan verifikasi dengan berbagai sumber data $^{26}$. Data yang sudah direduksi kemudian dianalisis dengan mengaku pada konsep teori yang digunakan dalam penelitian ini.

\section{Hasil dan Pembahasan}

\subsection{Pelaksanaan Penimbangan dalam Jual Beli Biji Coklat di Desa Bulili \\ Desa Bulili merupakan salah satu} desa yang berpotensial di bidang pertanian mayoritas masyarakat desa bermata pencarian sebagai petani biji coklat. Perkebunan coklat yang tersedia memberikan harapan bagi masyarakat dalam nuansa pereknomian di Desa Bulili ini. Salah satu yang sangat relevan dengan pembahasan ini adalah cara penjualan dan pengolahan.

Berdasarkan data penulis dapatkan dari hasil hasil wawancara dengan masyarakat desa Bulili bahwa sistem penjualan, yaitu dalam bentuk pernimbangan. Agar diketahui berapa berat biji coklat dan berapa yang harus dibayarkan. hubungan antara manusia sebagai individu atau sebagai anggota kelompok masyarakat dalam usaha memenuhi kebutuhannya. Ada macam-

25 Nurdin, N. (2017). To Research Online or Not to Research Online: Using Internet-Based Research in Islamic Studies Context. Indonesian Journal of Islam and Muslim Societies, 7(1), 31-54.

26 Nurdin, N., \& Yusuf, K. (2020). Knowledge management lifecycle in Islamic bank: the case of syariah banks in Indonesia. International Journal of Knowledge Management Studies, 11(1), 59-80. https:/ / doi.org/10.1504/ijkms.2020.105073

e-ISSN: $2686-6633$ 
macam bentuknya, ada yang berupa jual beli, hutang piutang, sewa menyewa, kerja sama dan sebagainya. Dari penelitian Penulis lakukan wawancara kepada masyarakat Desa Bulili. Dalam memenuhi kebutuhan hidup sehari-hari tidak cukup dengan hanya mengandalkan usaha bertani jangka pendek. Masyarakat setempat menjalankan usaha lainnya seperti usaha kerja jangka panjang dalam bentuk bertani biji coklat.

Penimbangan dapat diartikan sebagai proses penjualan kepada sesorang atau produsen. Umumnya harga yang dibayarkan berdasarkan berat biji coklat, yang dihasilkan oleh konsumen.

Di Desa Bulili pada umumnya, berat biji coklat yang dijual kepada pembeli sudah melalui proses pengeringan terlebih dahulu sehingga dari hasil pengeringan tersebut pihak pembeli dapat mengatahui berapa besarnya pemotongan kotoran biji coklat dan berapa berat kadar air dalam biji coklat tersebut. Untuk lebih jelas dapat kita lihat di tabel di bawah ini:

Tabel 2. Jenis Timbangan Biji Coklat

\begin{tabular}{|c|c|c|c|}
\hline No & $\begin{array}{c}\text { Jenis } \\
\text { Penjemuran }\end{array}$ & $\begin{array}{c}\text { Jumlah } \\
\text { perkilo }\end{array}$ & $\begin{array}{c}\text { Potongan } \\
\text { Perkilo }\end{array}$ \\
\hline 1 & $1-3$ Hari & $10 \mathrm{Kg}$ & $1-0,5 \mathrm{Kg}$ \\
\hline 2 & $1-5$ Hari & $10 \mathrm{Kg}$ & $0,5-1 \mathrm{Kg}$ \\
\hline 3 & $1-7$ Hari & $10 \mathrm{Kg}$ & $0-0,5 \mathrm{Kg}$ \\
\hline
\end{tabular}

Dari keterangan tabel 1.5 di atas dapat di ketahui bahwa jenis pemotongan yang ada di Desa berbedabeda, perbedaan pemotongan tersebut di sesuaikan dengan kotoran dan kadar air biji coklat tersebut dan juga lamanya hari penjemuran.
Praktek jual beli biji cokelat yang di lakukan di Desa Bulili sudah berlangsung sanga lama. Hal ini sebagai mana di sampaikan oleh kepala desa seempat.

"proses jual beli cokelat biji di desa ini sudah berlangsung sangat lama, sehinggah hal ini sudah menjadi kebiasaan bagi warga desa bulili, hal ini terjadi karena warga di desa bulili belum mampu mengelola biji cokelat menjadi bahan makanan atau makanan jadi, karena keterbatasan keilmuan dan ketersediaan alat yang memadai" ${ }^{27}$

Menurut salah satu warga desa yaitu bapak Ardin, selaku petani coklat "Pemotongan timbangan yang di lakukan oleh pembeli di desa bulili berdasarkan tingkat keringnya biji cokelat, biasanya petani menjual hasil panennya yang sudah di keringkan paling cepat selam tiga hari, apabila ingin tidak terlalu banyak potongan timbangan, maka harus di jemur selama lima sampai enam hari". ${ }^{28}$

Kotoran dan kadar air biji coklat tersebut dapat disesuaikan dengan hari penjemuran semakin lama penjemuran semakin kurang pula kotoran dan kadar air biji coklat tersebut oleh karena itu agar penjual tidak merasa rugi dengan potongan maka pihak pembeli menganjurkan kepada pihak penjual

${ }^{27}$ Jufri P, kepala Desa Bulili, "wawancara” 17 juni 2019.

${ }^{28}$ Ardin, "wawancara" dibulili, 17 juni,2019.

e-ISSN: 2686-6633 
agar mengerinkan terlebih dulu biji coklat tersebut.

Akan tetapi lama dan tidaknya sebuah penjemuran biji coklat pihak pembeli tidak pernah menurunkan harga sebelumnya. Hal ini dapat kita lihat pada tabel di bawah ini:

Tabel 2. Jenis Jemuran dan Harga Perkilo

\begin{tabular}{|c|c|c|c|}
\hline No & $\begin{array}{c}\text { Jenis } \\
\text { Penjemuran }\end{array}$ & Perkilo & Harga \\
\hline 1 & $1-3$ Hari & $1 \mathrm{Kg}$ & $28.000,00$ \\
\hline 2 & $1-5$ Hari & $1 \mathrm{Kg}$ & $28.000,00$ \\
\hline 3 & $1-7$ Hari & $1 \mathrm{Kg}$ & $28.000,00$ \\
\hline
\end{tabular}

Dari keterangan tabel 1.6 di atas dapat di ketahui bahwa jenis pemotongan pembayaran yang ada di desa tetap sama walaupun biji coklat tersebut belum dalam keadaan kering.

Dari hasil wawancara dengan Bapak Abdul Rahman

"Pada dasarnya Bayarannya tetap sama hanya saja berbeda pada potongan sesuai dengan hari penjemuran yang dilakukan karna setiap biji coklat mempunya kadar air, kotoran dan jamur dari biji coklat itu sendiri" ${ }^{29}$

Lebih lanjut Bapak Abdul Rahman menanbahkan

"Kami juga tetap harus melakukan pemotongan karna setiap biji coklat yang akan di simpan pasti akan berkurang jika kami tidak memotongnya maka di pastikan kami akan mendapatkan kerugian akan

\footnotetext{
${ }^{29}$ Bapak Abdul Rahman, "Wawancara" Di Bulili, Tanggal 15 Juni 2019.
}

tetapi harga yang kami ambilkan tetap sama hanya saja kami mengambil Rp 1000,00 dari harga yang ada di palu". ${ }^{30}$

Dari uraian di atas bahwa sistem pemotongan sesuai dengan hari penjemuran, dan para penjual di bayar dengan perkilo Rp. 28.000,00 dan jika penjual ingin menghindari pemotongan yang banyak maka penjual harus mengerinkan biji coklatnya dengan penjemuran 1 - 7 hari penjemuran. Dan sistem pemotongan ini juga tetap berlaku di luar desa penelitian penulis. Hal demikian sama dengan yang di ungkapkan salah seorang penjual biji coklat.

Dari hasil wawancara dengan bapak Jumail

"kami tidak pernah mendapatkan pemotongan harga walaupun kami hanya menjemur biji coklat kami 2-3 hari hanya saja pihak pembeli melakukan pemotongan timbangan akan tetapi pemotongan timbangan tersebut dilihat dari keringnya biji coklat tersebut jika matahari panas biasnya biji coklat cepat kering dan berkurangnya pemotongan akan tetapi biji coklat yang di kami jual tidak pernah mendapatkan pemotongan harga sebelumnya". 31

Berdasarkan pernyataaan yang di sampaikan oleh narasumber di atas, para pengepul atau tengkulak coklat di

\footnotetext{
${ }^{30}$ Bapak Abdul Rahman, "Wawancara" Di Bulili, Tanggal 15 Juni 2019.

${ }^{31}$ Bapak Jumail, "Wawancara" Di Desa Bulili, Tanggal 29 Juni 2019.
}

e-ISSN: $2686-6633$ 
desa Bulili tidak memainkan harga coklat, melainkan meraka memainkan timbangan, dan praktek pemotongan timbangan di lakukan di depan penjual, sehinggah ada kesepakatan bersama yang terjadi antara pembeli dan penjual coklat.

Pemotongan timbangan coklat juga di lakukan berdasarkan tingkat keringnya biji coklat yang akan di jual, apa bila coklat yang di keringkan atau di jemur selama tiga hari, maka pemotongan timbangannya akan lebih sedikit, hal ini di pengaruhi oleh tingkat kadar air yang terkandung di dalam biji coklat.

Kegiatan bekerja sebagai petani coklat yang dilakukan oleh masyarkat di Desa Bulili Kecamatan Nokilalaki Kabupaten Sigi dalam pengertianya adalah bagian dari kegiatan ekonomi Islam di bidang muamalah yang mengatur perilaku manusia dalam menjalankan hubungan ekonominya, sedangkan bentuk kegiatannya dalam konsep Islam kerja sama dalam jual beli. Dalam hal kerja sama setidaknya ada dua istilah dalam al-Quran yang berhubungan dengan perjanjian.

\subsection{Tinjauan Ekonomi Islam Terhadap Pelaksanaan Penimbangan Jual Beli Biji Coklat di Desa Bulili}

Pada dasarnya setiap manusia wajib berusaha demi memenuhi segala kebutuhan hidupnya. Manusia dapat melakukan berbagai cara untuk memenuhi segala kebutuhannya. Akan tetapi, tidak dengan jalan melanggar syariat-syariat yang telah ditetapkan Allah Swt. Salah satunya dapat dilakukan dengan melakukan suatu kegiatan usaha jual beli.

Dalam hal ini konsumen atau pembeli yang merasa tertipu, bukan yang baru lagi. Sering terungkap barang yang dibeli tidak sesuai dengan barang yang ditawarkan atau diiklankan. Atau ukuran barang tidak sesuai dengan yang disebutkan atau yang disepakati. Lebih sering lagi timbangan yang tidak sesuai dengan berat barang yang dibayar. Kalau di cermati, pembeli dapat memeriksa kembali berat kemasan barang misalnya berat gula atau beras yang beli. Kemungkinan berat yang berlabel $1 \mathrm{~kg}$ hanya berisi $0,9 \mathrm{~kg}$, atau yang berlabel $20 \mathrm{~kg}$ hanya berbobot 19,5 juga sering menyaksikan atau mungkin mengalami rasa tidak puas karena pelayanan pada setiap orang sebagai konsumen tidak seperti yang kita harapkan.

Di Desa Bulili penjualan biji coklat oleh si penjual kepada si pembeli itu dilakukan, dengan sistem timbangan. Allah SWT berfirman dalam surat AlAn'aam ayat 152 menegaskan apabila melakukan transaksi jual beli menggunakan timbangan mereka berkewajiban untuk memenuhi timbangan tersebut.

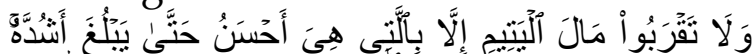

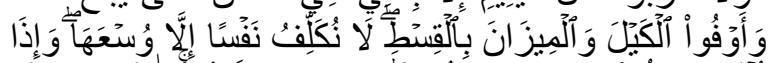

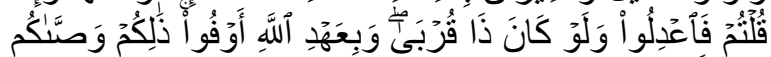

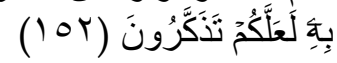

Terjemahannya:

"Dan janganlah kamu dekati harta anak yatim, kecuali dengan cara yang lebih bermanfaat, hingga sampai ia dewasa. Dan sempurnakanlah takaran dan timbangan dengan adil. Kami tidak memikulkan beban kepada sesorang 
melainkan sekedar kesanggupannya. Dan apabila kamu berkata, maka hendaklah kamu berlaku adil, kendatipun ia adalah kerabat(mu), dan penuhilah janji Allah. Yang demikian itu diperintahkan Allah kepadamu agar kamu ingat". 32

Prinsip kewajiban memenuhi timbangan terdapat juga dalam firman Allah SWT surat Al-Isra ayat 35 yang berbunyi:

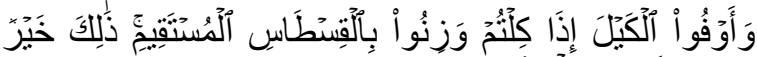

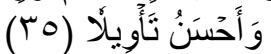

Terjemahannya:

"Dan sempurnakanlah takaran apabila kamu menakar, dan timbanglah dengan neraca yang benar. Itulah yang lebih utama (bagimu) dan lebih baik akibatnya". ${ }^{33}$

Adapun kenyataan yang terjadi di Desa Bulili dalam hal timbangan, pembelian biji coklat oleh pedagang sedikitnya sudah menerapkan ajaran Islam, mereka pedagang tidak mengurangi timbangan dan tidak merugikan si penjual dalam hal timbangan. Mereka menimbang timbanganya sudah tidak dalam keadaan goyang dan timbangan itu sudah sama berat lalu mereka menghitungnya. Pelaksanaan timbangan yang adil dan tidak merugikan si penjual yang dalam hal ini petani, suatu pelaksanaan penimbangan yang adil terhadap si penjual itulah yang sesuai dengan ajaran Islam.

\footnotetext{
${ }^{32}$ Departemen Agama RI, Al-Qur'an dan Terjemahny, 149.

${ }^{33}$ Departemen Agama RI, Al-Qur'an dan Terjemahnya, 285.
}

Rasulullah mengajarkan agar para pedagang senantiasa bersikap adil, baik, kerjasama, amanah, tawakal, qana'ah, sabar dan tabah. Sebaliknya beliau juga menasihati agar pedagang meninggalkan sifat kotor perdagangan yang hanya memberikan keuntungan sesaat, tetapi merugikan diri sendiri duniawi dan ukhrowi. Akibatnya kredibilitas hilang, pelanggan lari, dan kesempatan berikutnya sempit.

Keadilan merupakan pengakuan dan perlakuan yang seimbang antara hak dan kewajiban. Misalnya, jika kita mengakui hak hidup maka kita juga berkewajiban untuk mempertahankan hak hidup itu dengan bekerja keras tanpa merugikan orang lain karena orang lain juga memiliki hak hidup yang sama dengan kita.

Berdasarkan kesadaran etis, manusia dituntut untuk tidak hanya menuntut hak dan melupakan kewajiban. Jika manusia hanya menutut hak dan melupakan kewajiban, maka sikap dan tindakannya akan cenderung mengarah kepada pemerasan dan memperbudak orang lain. Sebaliknya, jika manusia hanya menjalankan melupakan kewajiban dan lupa menuntut haknya, maka akan mudah diperas atau diperbudak orang lain. Misalnya, hubungan antara majikan dan buruh, dosen dan mahasiswa, rakyat dan pejabat pemerintahan, pedagang dan pembeli, dan sebagainya perlu memahami keadilan tersebut, sehingga masing-masing tahu perananya mana hak dan mana kewajiban. Dengan begitu, mereka dapat menempatkan dirinya masing-masing pada posisi yang benar. Jika hal itu dapat dipahami 
bersama, maka yang dinamakan keseimbangan dan keharmonisan akan tercipta.

Perilaku jujur dan tidak jujur tidak dapat dipisahkan dari kehidupan manusia sehari-hari. Terjadinya korupsi, penyalahgunaan kekuasaan, plagiat, perselingkuhan, dan pembajakan hak cipta merupakan implementasi dari sebagian prilaku ketidak jujuram.

Pembelian disana menurut penulis tidak terdapat suatu kecurangan didalamnya, walaupun ada pemotongan dalam setiap timbangan akan tetapi pemotongan itu berdasarkan kesepakatan kedua belah pihak dan berdasarkan sebuah kualitas biji coklat tersebut. Pengurangan timbangan yang tidak di bolehkan adalah sesuatu yang tampah sepengatahuan penjual dan pengurangan secara paksa oleh pembeli inilah pangkal mula rusaknya perdagangan dan hilangnya kepercayaan seseorang.

Sifat-sifat kotor merupakan sifat umum yang dimiliki manusia ketika memasuki dunia bisnis. Mereka tidak terikat ruang dan waktu karena merupakan karakter mendasar manusia. Karena itu Islam membenarkan jalan yang terbaik untuk menyelesaikannya yaitu dengan mengikuti pesan-pesan Nabi Saw. Yaitu sifat-sifat yang terpuji. Jika pedagang menerapkan sifat terpuji maka hal ini menunjukan bahwa masyarakat pedagang khususnya dan masyarakat pada umumnya telah siap membangun dirinya sendiri dalam segala bidang kehidupan seperti politik, ekonomi, hukum, kebudayaan dan sebagainya.

Pedagang adalah pemegang amanat dari Allah untuk manusia, Allah memberikan amanat kepada pedagang untuk berdagang secara jujur dan benar. Menurut penulis pelaksanaan timbangan biji coklat yang dilakukan oleh pembeli itu sudah sesuai dengan ketentuan yang diajarkan oleh agama Islam, walaupun terdapat sebuah pemotongan dalam timbangan tetapi itu sumua atas dasar kesepakatan kedua belah pihak dan juga tampa adanya paksaan dari sala satu pihak. Dalam hal ini Sesuai dengan firman Allah dalam surat an-Nisa' ayat 29:

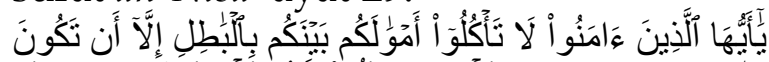

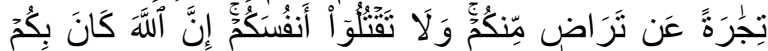

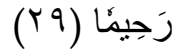

Terjemahanya:

"Hai orang-orang yang beriman, janganlah kamu saling memakan harta sesamamu dengan jalan yang batil, kecuali dengan jalan perniagaan yang berlaku dengan suka sama-suka di antara kamu. Dan janganlah kamu membunuh dirimu; sesungguhnya Allah adalah Maha Penyayang kepadamu". ${ }^{34}$

Dari pihak pedagang mereka tetap melakukan timbangan yang pas, dengan harga yang disepakati dengan penjual, serta pedagang juga menyebutkan kriteria biji coklat yang baik dan menjelaskan alasan terhadap akan terjadinya pemotongan timbangan kepada penjual, Hal demikian menunjukan sesuatu sifat yang jujur pembeli terhadap penjual.

Agar antara penjual dan pedagang tidak terjadi kerugian setelah menimbang dengan pas itu, baru

\footnotetext{
${ }^{34}$ Departemen Agama RI, Al-Qur'an dan Terjemahnya, (Marwah: Bandung, 2009), 83.
} 
dirundingkan masalah harga, pemotongan berat kadar air, berat kotoran dan berat jamur dan lain-lainya. Dan juga pedagang selalu memakai timbangan yang tampah merugikan si penjual. Dengan demikian cara itulah pembeli lakukan untuk menghindari sebuah kecurangan dalam penimbangan.

Kebebasan individu dalam melaksanakan kegiatan ekonomi terikat oleh ketentuan agama Islam yang ada dalam al-Quran dan hadis. Jual beli sebagai salah satu kegiatan dalam aktifitas perekonomian sangat dianjurkan untuk berlaku adil dan jujur didalam kegiatan tersebut. Sebagaimana yang terdapat dalam surat ar-rohman ayat 9 :

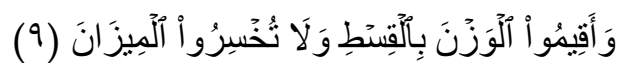
Terjemahanya:

"Dan tegakkanlah timbangan itu dengan adil dan janganlah kamu mengurangi neraca itu". 35

Pengertian ayat di atas menunjukan bahwa dalam berdagang kita tidak boleh berbuat curang dengan mengurangi takaran, ukuran atau timbangan. Setiap dalil di atas menyatakan hukum yang wajib bagi kita untuk menegakan timbangan, ukuran dengan benar. Kecurangan dalam menakar dan menimbang mendapat perhatian khusus dalam al-Quran karena prektek seperti ini telah merampas hak orang lain. Selain itu, praktek seperti ini juga menimbulkan dampak yang sangat vital dalam dunia perdagangan yaitu timbulnya ketidak

\footnotetext{
${ }^{35}$ Departemen Agama RI, Al-Qur'an dan Terjemahnya, 531.
}

percayaan pembeli terhadap pedagang yang curang.

Proses terjadinya kecurangan di dalam jual beli yaitu kurangnya keterbukaan antara pembeli dan penjual, praktek inilah yang sangat di tentang oleh agama Islam, karena islam sudah sangat jelas mengatur tata cara jual beli yang sesuai dengan syariat. Ada pun praktek yang di lakukan di desa Bulili tidak manjadi masalah karena praktek jual beli yang di lakukan dengan cara terbuka dan telah mencapai kesepakatan bersama sehinggah pihak penjual barang maupun pembeli sama-sama di untungkan.

Praktik pemotongan timbangan yang ada di Desa Bulili merupakan sebuah praktek yang di lakukan sudah sejak dahulu, hal ini sudah penulis jelaskan di atas. Petani cokelat di Desa Bulili, Kecamatan Nokilalaki, Kabupaten Sigi, hanya bisa menjual hasil panennya dalam bentuk utuh, bukan dalam bentuk bahan jadi, hal ini di karenakan kurangnya pengetahuan masyarakat dalam mengolah coklat menjadi bahan siap pakai, selain itu juga tidak tersediahnya alat yang memadai. Sehinggah petani tidak punya pilihan lain selain menjual cokelat biji.

Oleh karena itu pengurangan dan pemotongan timbangan yang dilakukan pedagang di Desa Bulili bukanlah sebuah kecurangan karena pemotongan timbangan itu berdasarkan sebuah kesepakatan dan juga telah disesuaikan dengan kualitas dari biji coklat konsumen itu sendiri sehingga hal demikian dapat dikatan pemotongan yang boleh-boleh saja karna didalam pemotongan tersebut terdapat sebuah kesepakatan antar kedua belah pihak 
dan tampa ada paksaan dari salah satu pihak sehingga sejauh ini penulis melihat Pelaksanaan Penimbangan Jual Beli Biji Coklat yang di terapkan di Desa Bulili merupakan bentuk jual beli yang dibolehkan dalam hukum Islam. Karena tidak bertentangan dengan syariat serta tidak mengandung unsur kedzaliman dan kemudharatan.

\section{Kesimpulan}

Hasil penelitian ini menyimpulkan bahwa dalam pelaksanaan jual beli biji coklat di Desa Bulili semua dilakukan atas dasar kesepakatan bersama dan atas dasar suka sama suka antara pihak penjual dan pembeli walaupun terjadi system pemotongan dalam setiap timbangan. Tanggapan petani biji coklat mengenai perihal pemotongan timbangan dalam jual beli biji coklat cukup beragam, namun pada dasarnya kebanyakan petani coklat merasa cukup puas dengan pemotongan karna melihat kualitas hasil panen mereka itu sendiri, mereka setuju dengan cara pembeli menimbang hasil panennya karna mereka bisah menyaksikan langsung penimbangan tersebut.

Secara tidak langsung pelaksanaan penimbangan jual beli biji coklat di Desa Bulili tidak melanggar syariat-syariat Islam di karenakan timbangan yang digunakan adalah timbangan yang di jamin atas ke normalannya dan juga transaksi tersebut atas dasar kerelahan dan suka sama suka antara pihak penjual dan pembeli ini sesuai dengan sabda Nabi Saw "jual beli dianggap sah kalau sudah ada kerelahan".

\section{Daftar Pustaka}

Ali, Atabaiq. 2003. Kamus Kontemporer Arab-Indonesia. Yogyakarta: Multi Karya Grafika.

Anoraga, Pandji. 2006. Manajemen Bisnis. Jakarta: Rineka Cipta

Arikunto, Suharsimi. 1993. Prosedur Ilmiah: suatu pendekatan praktek. Jakarta: RinekaCipta.

Ansel Struss dan Julet Corbin, DasarDasar Penelitian Kualitatif, (Yogyakarta : Pustaka pelajar, 2007), 5.

Asimun. 2019. "Wawancara" di Bulili, tanggal 15 juni

Asminiati. 2008 "Penimbangan Hasil Pertanian Di Pasar Agropolitan Jagalan Banjaroyo Kalibawang Kulomprogo DalamPerspektif Ekonomi Islam" Skripsi. Yogyakarta: UIN Sunan Kalijaga

Azzam, Muhammad. Abdul Aziz.2008 Fiqih Muamalat Sistem Transaksi Dalam Islam. Jakarta: AMZAH

B. Miles, Mathews. Tjejep Rohandi Rosidi, 1992. Analisis data kalitatif, Buku tentang metode-metode baru. Jakarta: UI-Pres.

Daud Ali, Muhammad. 2002. Pengantar Ilmu Hukum dan Tata Hukum Islam di Indonesia, Jakarta: PT. Raja Grafindo Persada.

Dedy, Sugono. 2008. Kamus Bahasa Indonesia, Jakarta: Pusat Bahasa.

Departemen Agama RI. 2009. Al-Qur'an dan Terjemahnya. Bandung: Marwah.

Dwi Cahyani, Ana. 2010. "Jual Beli Bawang Merah Dengan Sistem Tebasan Di Desa Sidapurna Kec Dukuh Turi Tegal (Sebuah Tinjauan 
Sosiologi Hukum Islam)" Skripsi. Yogyakarta: UIN Sunan Kalijaga.

Haroen, Nasrun. 2007. Fiqih Muamalah, Jakarta: Gaya Media Pratama.

Jumail. 2019. "Wawancara" di Bulili, tanggal 29 juni

Koentjaraningrat. 1991. Metode-metode Penelitian Masyarakat, Jakarta: Gramedia.

Lumin. 2019. "Wawancara" di Bulili, tanggal 15 juni

M Ali, Hasan. 2004. Berbagai Macam Transaksi Dalam Islam, Jakarta: PT Raja Grafindo.

Mudjab Mahallf, Ahmad. Ahmad Rodh Hasbulloh. 2004. Hadis-hadis Muttafaq 'Alaih, Jakarta: Kencana

Mudjahidin, Akhmad. 2007. Ekonomi Islam. Jakarta: PT Raja Grafindo.

Muhammad, Metodologi Penelitian Ekonomi Islam Pendekatan kualitatif, (Jakarta: Rajawali PT. Raja grafindo Persada, 2008), 12.

Nejjatulloh Siddiqi, Muhammad. 1996. Kegiatan Ekonomi Dalam Islam, Jakarta: Bumi Aksara.

Nurdin, N., Stockdale, R., \& Scheepers, H. (2014). The Role of Social Actors in the Sustainability of EGovernment Implementation and Use: Experience from Indonesian Regencies. System Sciences (HICSS), 2014 47th Hawaii International Conference on System Science,

Nurdin, N. (2017). To Research Online or Not to Research Online: Using Internet-Based Research in Islamic Studies Context. Indonesian Journal of Islam and Muslim Societies, 7(1), 31-54.

Nurdin, N., Pettalongi, S. S., \& Yusuf, K. (2018, 27-28 Sept. 2018).
Knowledge Management Model in Syariah Banking. 2018 5th International Conference on Information Technology, Computer, and Electrical Engineering (ICITACEE)

Nurdin, N., Novia, N., Rahman, A., \& Suhada, R. (2019). Potensi Industri Produk Makanan Halal Di Kota Palu. Jurnal Ilmu Ekonomi dan Bisnis Islam, 1(1), 1-12.

Nurdin, N. (2019). Knowledge Integration Strategy in Islamic Banks. In A. Helena \& S. Bernardete (Eds.), The Role of Knowledge Transfer in Open Innovation (pp. 118-138). IGI Global.

https:/ / doi.org/10.4018/978-15225-5849-1.ch006

Nurdin, N., \& Yusuf, K. (2020). Knowledge management lifecycle in Islamic bank: the case of syariah banks in Indonesia. International Journal of Knowledge Management Studies, 11(1), 59-80. https:/ / doi.org/10.1504/ijkms.20 20.105073

P. Subagyo, Joko. 1997. Metode Penelitian Dalam dan Praktek. Jakarta: Rimeka Cipta.

Rahman, Abdul. 2019. “Wawancara “Di Bulili, Tanggal 15 Juni

Sabiq, Sayyid. 1998. Fiqih Sunnah.Alih bahasa Oleh Mohd. Thalib, Bandung: PT al-ma'ruf.

Salim, Peter. Yeny Salim. 1991. Kamus Bahasa Indonesia Kontemporer. Jakarta: Moderen Engglish, Pers.

Suhendi, Hedi. 2002. Fiqih Muamalah, Jakarta: PT Raja Grafindo

Sulmianti. 2007. "Sistem Bagi Hasil Pertanian pada Masyarakat Tani 
Jurnal Ilmu Ekonomi dan Bisnis Islam - JIEBI

Vol. 2 No. 1 Tahun 2020

Desa Ranteleda Kecamatan Palolo

Kabupaten Donggala Menurut

Pandangan Hukum Islam" Skripsi.

Palu; STAIN Datokarama.

Suryabrata, Suryadi.1998. Metodologi

Penelitian, Jakarta: Raja Grafindo

Persada.

Syafe'i, Rachmat. 2001. Fiqich Muamalah,

Bandung: Pustaka Setia.

e-ISSN: $2686-6633$ 